\title{
New Zealand: A Trade-Led Economic Recovery
}

\author{
Clare Fearnley
}

COVID-19 has had a multitude of impacts on us all, from the way we live to the way we work. The social and economic impacts have been significant, and not evenly spread - the pandemic has had a devastating impact in some parts of the globe.

For diplomats, who are used to hopping on planes frequently and finding themselves posted in different parts of the world in their professional roles, we are now living with a reduction in the people-to-people connection that comes with being able to travel and which has always been a vital part of our job. To some extent, we can mitigate that with the digital tools we have available. While video conferencing technologies may help to keep connectivity going, they cannot move goods (or people) across the world.

The export economy is hugely significant to New Zealand; one in four New Zealand jobs depends on exporting. For this reason, New Zealand has been focused on enabling a trade-led economic recovery from COVID-19. At the start of the pandemic, New Zealand moved quickly to keep supply chains open for essential trade, maintain connectivity and work with other governments to remove trade barriers. We wanted to keep trade flowing to support our economy.

That is what our Trade Recovery Strategy aims to achieve. It has been created to help New Zealand recover from the impacts of COVID-19 and to seize new opportunities for exports and investment. It consists of four pillars of work to position New Zealand for recovery from the economic impacts of the pandemic: retooling the support and facilitation we provide exporters; building New Zealand's strategic economic resilience; refreshing key trade relationships; and reinvigorating the international trade architecture. It is this last item that I wish to focus on in this article.

\footnotetext{
C. Fearnley $(\bowtie)$

Embassy of New Zealand to the People's Republic of China, Beijing, China
} 


\section{The Importance of Openness and Coherence for Growth and Resilience to Future Crises}

New Zealand is a strong supporter of free and open trade. The sudden uptick in protectionist measures after the COVID-19 pandemic struck in 2020 was alarmingby March 2021, WTO Members had taken over 450 new measures affecting trade in goods or services, or intellectual property rights. New Zealand took the opposite approach-one of openness. We believe that international cooperation, and not national protectionism, is the best way to address a global challenge.

As the COVID-19 crisis unfolded, we acted quickly, working closely with tradeoriented partners to ensure that New Zealanders could access essential goods, like medicines and PPE, and ensure that our goods continued to reach our trading partners.

We unilaterally removed tariffs on essential goods, and we sent strong political signals of our commitment to open trade flows and supply chain connectivity.

For example:

- With Singapore we drafted a Joint Ministerial Statement affirming commitment to ensuring supply chain connectivity amidst the COVID-19 situation. This affirmed our commitment to sustain open trade and supply chain connectivity, including refraining from imposing export controls and tariff or nontariff barriers, and removing any existing trade restrictive measures on essential goods, especially medical supplies. Others agreed, and the statement now has 12 ministerial signatories, including China. New Zealand and Singapore also launched the Declaration on Trade in Essential Goods for Combating the Covid-19 Pandemic, a trade initiative to ensure supply chain connectivity and the removal of blockages to trade in a list of essential products. The list included PPE equipment, medical equipment, nutritional products, medicines and hygiene supplies for which participants undertook to remove tariffs and facilitate trade. The Declaration also called for participants not to apply export restrictions on food and beverage products and to facilitate trade in food and beverage.

- New Zealand joined 78 other WTO Members undertaking not to impose export restrictions in relation to the World Food Programme's activities.

- New Zealand continues to work with other Ottawa Group Members to promote a WTO Declaration on Trade and Health that demonstrates how international trade policy can contribute to successfully fighting COVID-19 and any future pandemics.

- New Zealand has co-sponsored a WTO proposal with Canada, Australia, Chile, Colombia, Turkey, Norway, Panama and Paraguay that aims to enhance the role of the WTO in the global effort to produce and distribute COVID19 vaccines and medical products. The proposal encourages the WTO to collaborate with the WHO, manufacturers and developers to increase COVID19 vaccine production and to identify trade-related impediments to use and upscaling of vaccine manufacturing capacity. 


\section{Rebuilding a Strong WTO}

Last year was one of the most challenging years for the multilateral trading system since the WTO was established. Not only did the pandemic affect global trade flows and openness, but the WTO infrastructure was unable to respond as effectively as it might have.

WTO reform is a key pillar of New Zealand's Trade Recovery Strategy. Reform is important for ensuring that the WTO works more effectively in the interests of all. It will provide for a more resilient recovery, and the inclusive and sustainable growth and development through trade that all members are seeking.

In undertaking reform, we need to make sure that we have strong, flexible and resilient institutions capable of withstanding a variety of different pressures, rather than simply looking backwards to design our response to fit the last crisis.

This requires focusing on the fundamentals of open trade and non-discrimination and ensuring that the WTO can deliver its core functions of negotiations, monitoring and dispute settlement.

The WTO needs to demonstrate that it can deliver further openness. The priority is to conclude ambitious disciplines on fisheries subsidies, underscoring the WTO's ongoing role as an effective negotiating body, as well as contributing to sustainable development.

Restoring a fully functioning Appellate Body as soon as possible will be fundamental for ensuring openness is maintained in practice and guarding against protectionism.

New Zealand is also a strong supporter of modernizing WTO rules-for example on digital trade. Progress on trade and climate issues, such as through fossil fuel subsidy reform, will ensure that fixing international trade is not at the expense of the planet.

\section{Open Plurilateralism}

New Zealand supports multilateral efforts as the most effective way to respond to questions of global concern. However, it takes a long time to get 164 WTO Members to agree on anything.

In the meantime, we can further bolster the rules-based system by pursuing "concerted open plurilateralism", i.e. international agreements amongst subsets of willing participants able to move more quickly, with clauses that allow any other WTO Member to join if they can match the standard of commitments set by the original partners.

Examples include:

- Joint Statement Initiatives launched in Buenos Aires at the 11th WTO Ministerial Conference to advance rules on electronic commerce and services domestic regulation, and investment facilitation for development. 
- FTAs with open accession clauses like the Comprehensive and Progressive Trans Pacific Partnership (CPTPP) and the Regional Comprehensive Economic Partnership. We welcome participation from those willing to meet the high standards of these agreements. In the case of CPTPP, New Zealand acts as the depositary for accession requests.

- Sectoral agreements like the Digital Economy Partnership Agreement (DEPA) signed in June 2020 by Chile, Singapore and New Zealand, and which came into force for Singapore and New Zealand on 7 January 2021. Canada formally notified DEPA parties of its interest in joining the agreement at the end of 2020.

- New Zealand's negotiations for an Agreement on Climate Change, Trade and Sustainability (ACCTS) with Costa Rica, Fiji, Iceland, Norway and Switzerland.

Open plurilateralism recognizes that in order to move ahead at the WTO, we may need to be more creative in our approaches, while still respecting fundamental principles of openness, transparency and consistency with WTO disciplines.

We have seen that FTAs can show possible solutions to issues that have proved difficult to progress at the multilateral level—for example, there are already binding disciplines on fisheries subsidies in the CPTPP.

FTAs can also be building blocks for a coherent expansion of regional rules. For example, the ASEAN-Australia-New Zealand FTA (AANZFTA) provided a basis for New Zealand's involvement in the Regional Comprehensive Economic Partnership (RCEP), while the "P4" agreement between Brunei, Chile, Singapore and New Zealand provided the basis for TPP negotiations and then the conclusion of CPTPP. In turn, we hope that these agreements will inform a regional Free Trade Area of the Asia-Pacific through Asia-Pacific Economic Cooperation (APEC).

\section{APEC}

Non-binding forums, such as APEC, also have an important role as safe spaces to generate innovate ideas and build coherent regional practice through technical exchanges.

In New Zealand's APEC 2021 host year, an integral pillar of work is the region's response to COVID-19, mapping out a sustainable and inclusive response that delivers for all. New Zealand has sought to:

- encourage trade and economic policies that support openness and connectivity and reduce friction at the border. The goal is to reduce barriers, making it easier for companies to trade and do business through the APEC region;

- enhance the participation of groups such as women and indigenous people in the economy and ensure that their contributions are valued;

- ensure that the recovery can be used to improve sustainability outcomes including in the area of climate change and

- take advantage of innovation in the digital space. 
New Zealand has also pursued meaningful work on practical steps to support and advance the efforts of APEC economies in the WTO. This includes work to monitor and help economies to implement the WTO outcomes from the fisheries subsidies negotiations; to achieve strong WTO commitments on trade- and productiondistorting subsidies; and to support negotiations of the Joint Statement Initiatives. As a non-binding forum, APEC is well placed to discuss new and emerging trade issues for future consideration by the WTO, including issues around inclusion and sustainability, such as identifying COVID-19 essential goods and services, agreeing an updated list of environmental goods and developing a new set of environmental services.

The world's economic recovery from COVID-19 depends on regional and international trade cooperation. APEC will play an important role in this, as the AsiaPacific's preeminent trade and economic forum. APEC's strength has always been in its ability to bring people together, to share experiences and ideas and to test practical solutions to shared economic and human challenges. The theme for New Zealand's host year draws on this tradition. In te reo Māori (the Māori language), it is Haumi $\bar{e}$, Hui è , Tāiki ée-Join, Work, Grow. Together.

\section{New Zealand-China Trade}

As New Zealand's largest trade partner, we anticipate that China will have an important role to play in New Zealand's recovery from the economic impact of COVID-19. Our goods exports to China were down just half a per cent last year after a record year in 2019 — not a bad result. But not all sectors fared as well as others. Sectors like forestry and seafood were hit particularly hard early on by the challenging market conditions that COVID helped create. Our services exports were also down considerably.

While the movement of people between our two countries has been very challenging this past year, maintaining air and sea links has been essential to keeping goods trade flowing amid significant disruption to supply chains. New Zealand officials worked hard over the last year to maintain sea and air connectivity between our two countries. These connections have been important both for the import of PPE and respiratory equipment from China to help New Zealand's COVID-19 response and to maintain our exports to China amid ongoing disruption.

The signing of the New Zealand-China FTA Upgrade in January 2021 is another strand in our Trade Recovery Strategy. Our existing bilateral FTA from 2008 has been a platform for closer trade and economic cooperation, with two-way trade having more than tripled in that time to NZD 32 billion. The Upgrade modernizes the FTA by updating the rules underpinning our trade to ensure that they remain fit for purpose in today's trading environment.

Key outcomes of the Upgrade include new rules that will make exporting easier and reduce compliance costs, a better deal for services exporters through expanded market access and most-favoured nation commitments and the most ambitious trade 
and environment chapter with the highest level of commitment that China has agreed to in any FTA. For New Zealand, the Upgrade also includes new goods access for wood and paper products, as well as further services market access. And for China, temporary employment entry is a better fit with demand.

Importantly, the signing of the Upgrade also sends a positive signal to the world of our two countries working together against the challenges posed by COVID.

\section{Conclusion}

For most of us, COVID-19 has been the greatest challenge to our societies and our economies in more than a generation. For New Zealand, part of the answer to rebuilding our economy lies in a trade-driven response achieved through international cooperation at every level: a strong, effective WTO that can reform multilateral trade rules for the benefit of all; new regional trade architecture that is open to anyone willing to meet and comply with the high standards set; and refreshing key bilateral relationships. New Zealand's Trade Recovery Strategy aims for such outcomes, combined with giving our exporting businesses the tools and knowledge they need to thrive internationally. This approach is also consistent with New Zealand's values and long-standing support for multilateralism and rules-based systems. Haumi $\bar{e}, \mathrm{Hui}$ $\bar{e}$, Täiki $\bar{e}$.

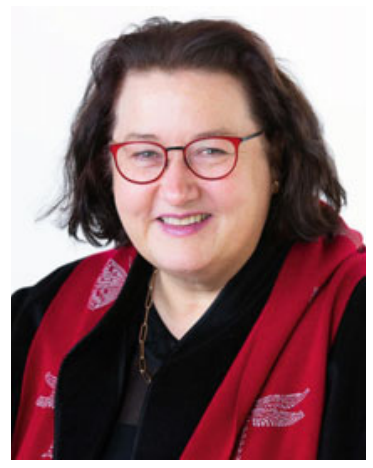

H.E. Ms. Clare Fearnley is the ambassador of New Zealand to the People's Republic of China and is cross-accredited to Mongolia. Prior to this, Ms. Fearnley was ambassador in Seoul (2015-2017), cross-accredited to Pyongyang. Ms. Fearnley's most recent role at the Ministry of Foreign Affairs and Trade in Wellington was as Director-General for North Asia (2014) and before that she was Director-General for Asia-Pacific Regional work (2011-2014). Ms. Fearnley has degrees in arts and law from Canterbury University (NZ). She is a Mandarin speaker and studied at Peking University and Beijing Languages Institute in the 1980s. 
Open Access This chapter is licensed under the terms of the Creative Commons AttributionNonCommercial-NoDerivatives 4.0 International License (http://creativecommons.org/licenses/bync-nd/4.0/), which permits any noncommercial use, sharing, distribution and reproduction in any medium or format, as long as you give appropriate credit to the original author(s) and the source, provide a link to the Creative Commons license and indicate if you modified the licensed material. You do not have permission under this license to share adapted material derived from this chapter or parts of it.

The images or other third party material in this chapter are included in the chapter's Creative Commons license, unless indicated otherwise in a credit line to the material. If material is not included in the chapter's Creative Commons license and your intended use is not permitted by statutory regulation or exceeds the permitted use, you will need to obtain permission directly from the copyright holder.

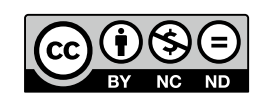

